\title{
An Economic, Hydrologic, and Environmental Assessment of Water Management Alternative Plans for the South Central Texas Region*
}

\author{
Dhazn Gillig \\ Assistant Research Scientist \\ Department of Agricultural Economics \\ Texas A\&M University \\ College Station, TX \\ dgillig@taexgw.tamu.edu \\ (979) 845-3153
}

\author{
Bruce A. McCarl \\ Professor \\ Department of Agricultural Economics \\ Texas A\&M University \\ College Station, TX \\ mccarl@tamu.edu \\ (979) 845-1706 \\ and \\ Frederick Boadu \\ Associate Professor \\ Department of Agricultural Economics \\ Texas A\&M University \\ College Station, TX \\ f-boadu@tamu.edu \\ (979) 845-4410
}

\footnotetext{
*This work is being funded by the Texas Educational Coordinating Board through the Advanced Research/Advanced Technology Program and by the Texas Agricultural Experiment Station. The authors thank Steven Raabe at the San Antonio Water Authority; Agatha C. Wade, John Waugh, and Darren Thompson at the San Antonio Water System; Steven Walthour at the Edwards Aquifer Authority; and Sam Vaugh at HDR Engineering, Inc. for useful discussions.
} 


\begin{abstract}
Regional water scarcity has motivated the South Central Texas Regional Water Planning Group to actively engage in the development of water plans to address long-term and short-term regional water needs. This study, therefore, develops an integrated Edwards Aquifer groundwater and river system simulation model to determine the "best" choice of regional water management plan using mixed-integer mathematical linear programming. The economic, hydrologic, and environmental consequences of the "best" choice of regional water management plan and of other water management options are evaluated and compared. Results indicate a tradeoff between the economic and environmental benefits. A slight decrease in economic benefit will result in a substantial increase in environmental benefit.

Key words: Economic and hydrologic assessment, Edwards Aquifer, and water management plans.
\end{abstract}




\section{An Economic, Hydrologic, and Environmental Assessment of Water Management Alternative Plans for the South Central Texas Region}

According to the South Central Texas Regional Water Planning Group (SCTRWPG), the region will need to expand water supply or reduce demand by approximately $25 \%$ of projected needs by 2050 . In addition, regional water supply from the Edwards Aquifer will be reduced due to the restrictions imposed in Texas Senate Bill 1477. ${ }^{1}$ This regional water scarcity has motivated the SCTRWPG to actively engage in the development of water plans to address long-term and short-term regional water needs.

As part of its process, the SCTRWPG has identified 57 water management options and has developed five proposed long-term plans consisting of combinations of these options. In general, these water management plans focus on transferring surplus (ground/surface) water to water deficient areas, exchanging, purchasing, or leasing water rights among users, developing new reservoirs, enhancing the Edwards Aquifer recharge and storage, and reusing Edwards Aquifer water (details on water management alternatives can be viewed at http://www.watershedexperience.com/plans/).

The challenge for regional water management is to simultaneously: a) provide water to meet rising demand, b) maintain and enhance regional economic net benefits, and c) preserve the regional environment. Conflicts will, and have arisen, as illustrated by the endangered species-based lawsuit filed by the Sierra Club in 1991 or the lawsuits over water rights (i.e., the Edwards Aquifer Authority - Bragg suit over pumping rights - U.S. Water News). Choice among alternatives will involve water availability, economic benefits, and costs accruing to involved parties, and environmental impacts. This paper presents a model-supported analysis of the regional ground and surface water systems and associated economic and hydrological aspects considering these impact measures and the proposed regional options and plans. Specifically, this study develops an integrated Edwards Aquifer groundwater and river system simulation model (EDSIMR) and uses it to:

1) Determine the "best" mix of water management options for a given demand and 
environmental constraint scenario,

2) Evaluate the economic and environmental consequences of a set of water management plans chosen by the SCTRWPG,

3) Undertake a comparative assessment of the model "best" and SCTRWPG plans.

\section{Description of Ground/Surface Water Systems ${ }^{2}$}

The study area consists of the Edwards Aquifer (San Antonio portion) along with the Nueces, Frio, Blanco, San Antonio, and Guadalupe River Basins (Figure 1). The Edwards Aquifer (EA) underlies a crescent-shaped area in Texas extending from Brackettville in Kinney County, to San Antonio, and ending at Kyle in Hays County. It is a major source of water for more than two million people - serving agriculture, municipalities, industry, recreationists, and environmental needs. The San Antonio municipal area meets its water demand almost exclusively from the EA.

The EA recharges and discharges rapidly. Recharge greatly fluctuates depending on rainfall. For example, in 1956 recharge was 43,700 acre feet (acft) whereas it was 2,003,643 acft in1987 (Figure 2). The EA discharges naturally through springs. The two largest, Comal Springs and San Marcos Springs, support habitat for endangered species (Longley). There is also considerable pumping amounting to $45 \%$ of average recharge. In 1996, 37\% of total well discharge supported agricultural consumption mostly in the western counties and the remaining $63 \%$ supported municipal and industrial consumption mostly in the eastern counties.

There are three associated river systems that interact with each other through the EA and regional water system. The Nueces River System originates above the EA, flows across it contributing $59 \%$ of the total recharge (USGS), and eventually enters the Corpus Christi Bay. Two important reservoirs, Choke Canyon Reservoir and Lake Corpus Christi, located below the recharge areas, provide water for the City of Corpus Christi and surrounding areas. Tradeoffs exist on this river between recharge and downstream water supply. The Nueces River also supports irrigation. The San Antonio River System both recharges and gains flow from the EA. Its waters provide an average of $38 \%$ of the total Edwards Aquifer recharge (USGS). In addition, 50\% of average base flow comes from return flow out of San Antonio's use of EA 
waters. Downstream use is mainly agricultural, but non-agricultural use is expected to grow rapidly in the greater San Antonio region. The Guadalupe River System provides about 6\% of EA recharge and receives about $22 \%$ of its average base flow from the EA springs (USGS). Water use in the basin is primarily for irrigation (55\%) and for cities and industries (45\%) (HDR 1993).

\section{Model Development}

The Edwards Aquifer Simulation Model (EDSIM, see the review in McCarl et al. for details on model development and scope) was expanded for this study to include surface water flows and aquifer interdependencies in the Nueces, San Antonio, and Guadalupe Rivers. This linked EA - river model is referred to as EDSIMR in the paper. Monthly flows in the rivers are incorporated in the form of a network flow model depicting flow between river/reservoir reaches which were specified based on data from USGS stream gauges and data provided by HDR Engineering, Inc. (HDR 1991, 1993, and 1999). The river systems are hydrologically connected to the EA through aquifer recharge, spring discharge, and return flow. ${ }^{3}$

EDSIMR operates across a ten-state representation of the probability distribution of recharge and associated precipitation ranging from very dry to very wet years. The probability distribution is an empirical distribution based on the historical recharge of the Edwards Aquifer data for the period 1934 to 1996. The years included, ordered from most dry to most wet, are: 1956 (annual recharge at 43,758 acft), 1951, 1963, 1989, 1952, 1996, 1974, 1976, 1958, and 1987 (annual recharge at 2,003,643 acft).

\section{Theoretical Structure}

EDSIMR is a price-endogenous mathematical program composed of about 100,000 continuous variables, and 35,000 constraints in a General Algebraic Modeling System (GAMS) (Brooke et al.). The objective function maximizes the expected net benefits (benefits minus costs) of water use by municipal, industrial, and agricultural sectors. Water use is drawn from regional groundwater or surface water depending upon availability at a particular site. The region is subdivided into east and west for use from the EA along with 52 river reaches and two other regions for use of non-EA water. Demand curves are specified for municipal and industrial (M\&I) water based on estimates by Griffin and Chang, and 
Renzetti, and by county with discretionary and non-discretionary uses differentiated in Bexar County (where San Antonio is located). Agricultural use and demand is developed using 65 regional linear programming models defined for particular river reaches or groundwater usage areas which could pursue irrigated and/or dryland crop production. The model contains constraints on ground/surface water demand and supply availability, agricultural crop mixes, pumping lift formation, possible springflow or water use regulations, and nonnegativity conditions. Details on the theoretical structure and assumption are presented in Appendices B and C, respectively.

\section{Stochastic Structure}

EDSIMR is implemented through use of a two-stage (Dantzig) or discrete stochastic programming model considering variability in yields and resource usage. The stochastic events are defined by recharge and associated weather/crop yields. The formulation assumes that activities at the first stage (i.e., crop mix, initial aquifer level, and initial lake level) are independent of recharge and/or weather (since weather and recharge are unknown until later in the crop year). For example, farmers make acreage decisions before actual recharge is known. Later in the second stage decision, the state of recharge nature becomes known, and the practices vary accordingly to the state of recharge nature (i.e., the irrigation schedule is based on rainfall and water supply availability).

\section{Incorporation of Water Management Alternatives}

Fifty-seven water management options identified by the SCTRWPG are included into EDSIMR as integer variables (Table 1 and Appendix A). All the regional water management options entail incurring fixed costs in terms of infrastructure investments that must be chosen and constructed before being used. For example, one option involves transfer of water from the Guadalupe River to Bexar County, but this cannot proceed unless fixed costs are incurred for transfer and treatment facilities construction. In deciding which options to include, EDSIMR makes a tradeoff between the water supply benefits and the investment fixed costs.

The nature of supply options merit further discussion. These decisions - whether or not water management options should be adopted - are depicted as integer variables choices, build or not build, 
with amortized fixed costs and capacities involved. The amortized fixed cost of each option is entered in the objective function. The amount of water that can be drawn from each water management option is limited by the capacity of each water management alternative plan, and its corresponding variable cost is considered in the objective function. Water supply alternatives are highly stochastic depending on the state of weather conditions, especially when they are developed from surface water diversions. Not all of the water management options are developed to increase new sources of water supply, rather some are developed to maintain the regional environmental benefits at springs or estuary bays.

In addition, there are joint constraints between the development alternatives expressing:

A. Interdependencies between management options, that is, surface water from the San Antonio or Guadalupe Rivers cannot be diverted to Cibolo Reservoir unless Cibolo Reservoir is built.

B. Mutual exclusivity between some options (for example, there are several ways of operating Cibolo Reservoir which cannot simultaneously occur).

\section{Maximization Procedure}

With a set of water management options incorporated, EDSIMR chooses options to maximize net regional economic value. The model is set up under projected 2050 water demand and the 400,000 acft EA pumping limit. ${ }^{4}$ Regional economic value is derived from a combination of perfectly elastic demand for agricultural products, agricultural production costs, price elastic municipal demand, price elastic industrial demand, and lift sensitive pumping costs. The municipal demand elasticity is drawn from Griffin and Chang while the industrial elasticity is obtained from Renzetti. Following Griffin and Chang, the quantity demanded by municipal users depends on rainfall and climatic conditions.

\section{Data}

\section{Water Demand and Supply}

The data used in the study included historical and projected groundwater and surface water demands by user; hydrological data on naturalized and gauged streamflow; river or reservoir evaporation factors; return flow factors; reservoir elevation, area, and storage capacity; the Edwards Aquifer recharge 
and discharge; and the Carrizo Aquifer recharge and discharge throughout the study area. The data were obtained from the Texas Natural Resource Conservation Commission, the Texas Water Development Board, the US Geological Survey, HDR Engineering Inc., the Nueces River Authority (NRA), the San Antonio Water System (SAWS), the Guadalupe Blanco River Authority (GBRA), the Bexar-MedinaAtascosa River Authority (BMA), and the Zavala-Dimmit Water Improvement District No. 1. To compute how municipal water demand fluctuates according to the recharge state of nature, the projected municipal water demand is multiplied by the climate elasticity (Griffin and Chang), the number of days with less than 0.25 inches of rain, and the temperature.

\section{Weather}

Weather is defined to include temperature, precipitation, and number of days having a precipitation greater than 0.25 inches. The data covered the period 1950 to 1996 and were grouped by county. The two sources of weather data were the Office of the Texas State Climatologist and a webbased weather information system developed by the University of Utah.

\section{Agricultural Activities}

Data on the crop and vegetable production activities were obtained from the Texas Agricultural Experiment Station crop enterprise 1995 budgets for district 10 (Southwest Texas), 11 (Texas Coastal Bend), and 12 (South Texas). Historical crop mixes from 1975 to 1995 were obtained from the Texas Agricultural Statistics Survey. Additional information on the quantity and price of quota peanuts and non-quota peanuts for the period 1994 to 1999 was provided by the Farm Service Agency located in College Station, Texas. The Blaney-Criddle method (Heimes and Luckey and Doorenbos and Pruitt) and the Erosion Productivity Impact Calculator simulation (Williams et al.) were applied to adjust crop and vegetable yields, and water requirements consistent with a defined state of weather conditions. Costs

The water development costs included fixed costs of constructing facilities and other nonstructural costs relating to construction activities, variable costs of operation and maintenance, and other costs. These cost data were obtained from the South Central Texas Regional Water Plan (1999 and 
2000). Agricultural and non-agricultural pumping/diversion costs were obtained from various river authorities and municipal agencies. These costs are further specified as a function of pumping lift. While pumping lift of groundwater is determined by J17 and Sabinal wells ending elevation levels, surface water lift depends upon the stream level which is influenced by weather.

\section{Results and Discussion}

\section{Calibration and Validation}

The EDSIMR was set up with 1996 water demand and agricultural price data. The graphs shown in Figure 3a and 3b compares the EDSIMR solution with 1996 observed data. These figures indicate that EDSIMR is able to produce results relatively close to the 1996 observed data for springflow and water demand. Thus, it is used for further experimentation.

\section{Developing an Optimum Mix of Alternatives}

A set of optimal regional water plans were developed by solving the model under 2050 projected water demand and the following three development alternatives:

1) No new water development permitted and the 400,000 acft pumping limit that will be imposed by Senate bill 1477 by the year 2008 .

2) All water development alternatives allowed with the 400,000 acft pumping limit.

3) All water development alternatives allowed but with a springflow minimum limit imposed at Comal Springs, where the springflow is set to be at least $200 \mathrm{cfs}$ (the take level specified by the Fish and Wildlife Service), but EA pumpage is unlimited.

The water plan alternatives chosen are summarized in Table 1. The model results for water use by sector, economic welfare, hydrology, and environmental attributes were observed for the specified water development alternatives. The results are summarized in Table 2. Results under the 2050 no development alternative are displayed as actual values whereas results under the other plans are displayed as an absolute value deviation from the 2050 base results.

The 2050 without a water development alternative leads to a situation where the full projected increase in 2050 regional water demand is not met leading to a shortage of 400,000 acft in the regional 
water supply, especially in the San Antonio region. This results in much higher water prices and the stimulation of conservation through pricing. The model reacts to this in several ways:

1) To the extent possible, water is shifted from agriculture to the cities (although the development alternatives allow much more of this to go on).

2) Springflow at Comal and San Marcos Springs falls and the estuary bay flows at Corpus Christi Bay and Calhoun Bay decrease by $75 \%-90 \%$.

On the other hand, when the water development alternatives are allowed (the optimal 400 scenario), the optimal choice of water management options scenario involved eight of the 57 water management options (Table 1). The broad characteristics of this solution are that:

1) The water deficit relative to the projection is reduced by $250,000 \mathrm{acft}$. Not all of the water deficit is made up because of the cost of the new development alternatives interacting with the demand elasticity.

2) Even more water is shifted from agricultural to non-agricultural users.

3) A $78 \%$ reduction in the EA agricultural use occurs with non agricultural users purchasing 41,700 irrigated acres and leasing 700 irrigated acres plus some land switching water supply to other aquifers.

4) The welfare of non-agricultural party increases only slightly since they must also pay for the new water development options (Table 3).

5) The EA agricultural sector loses a third of its income because half of the current irrigated land is converted to dryland. The agricultural income per acre decreases by $\$ 100$ from the 2050 base. However, the agricultural sector receives an annual compensation of $\$ 2.3$ million from land retirement and leasing, and would also gain from purchase of water rights.

6) Overall welfare increases by $\$ 10$ million compared to the 2050 base.

7) Despite the 400,000 acft pumping limit, springflow decreases (Figure 4). One explanation for this result is that the M\&I water use is less stochastic and also more skewed toward the summer months in comparison to agriculture. 
8) The average ending elevation measured at the J17 well decreases by 9.2 feet.

9) Freshwater inflows to the bays are reduced. This occurs since one of the selected water options diverts unappropriated streamflow and existing water rights downstream in the Guadalupe River, thus reducing the water that could flow into the bay.

Under the springflow limit (the Optimal 200 scenario), the optimal choice of water management options is identical to those chosen under the optimal 400,000 acft scenario with the addition of the springflow recirculation option. The overall results are that:

1) The water deficit relative to the projection is reduced by another 14,000 acft to a total of $260,000 \mathrm{acft}$.

2) Farmers not only retire a part of their irrigation water rights, but also add the option to switch to use of waters from Carrizo, Gulf Coast, and Trinity Aquifers rather than surface waters.

3) The EA agricultural sector exhibits less of an income reduction than under the Optimal 400.

4) A 58\% reduction in the EA agricultural use occurs with non-agricultural users purchasing 30,900 irrigated acres and leasing 1,500 irrigated acres plus some land switching of water supply to other aquifers.

5) The welfare of the EA non-agricultural sector decreases slightly mainly due to additional water development costs (Table 3).

6) Average annual springflow at Comal Springs is higher as mandated by the constraints.

7) Meeting the springflow restriction imposes a cost to the region of approximately $\$ 16$ million compared to the Optimal 400. In other words, the tradeoff between the regional welfare for an additional acft of springflow is $\$ 140$.

8) The increased springflow comes at an environmental cost in terms of freshwater inflows to Calhoun Bay due to a diversion of flow in the Guadalupe River to recirculate back to the EA which has not been considered under the Optimal 400.

\section{Evaluation of Regional Water Plans}

The model was also used to evaluate five proposed SCTRWPG plans for regional water 
management. The water development options defining these plans are identified in Table 1 under the columns labeled Plan1 - Plan5 while the results from those plans are in Table 2.

Each plan has a different focus. Plan1 focuses on developing new sources of water drawn mainly from groundwater and surface water. Plan 2 focuses on the least detrimental impact to environment first, then on its implementation costs. Plan 3 emphasizes four criteria - unit cost of water, environmental impacts, reliability under drought, and public acceptance. Plan 4 posits a cooperative effort in developing water supplies between the SCT region and the Lower Colorado and the Coastal Bend Regions. Plan 5 is based on the maximization of the EA recharge and recirculation system. The recirculation is used as a means to increase total water storage in the EA.

economic impacts

Compared to the 2050 base, the Optimal 400, and the Optimal 200 Plans, all of the five proposed SCTRWPG Plans lead to losses in regional welfare. These losses were borne mainly by the EA nonagricultural sector. These losses occur mainly because of water development costs, ranging from $\$ 500$ to $\$ 1,200$ per acft (Table 3). The EA agricultural sector is worse off under these plans. The loss in the EA agricultural sector is due to the transfer of irrigated land production to dryland production as a result of the retirement of irrigated land. Despite an increase in water consumption to the EA non-agricultural sector, the EA non-agricultural sector is still worse off since the water development costs exceed the benefits of water which in turn depresses the EA non-agricultural surplus.

environmental impacts

Plans 2 and 3 achieve their goal of maintaining desirable environment through the Medina Lake irrigation reduction and the spring enhancement (recirculation). Buying irrigation water rights from the Medina Lake leaves extra water remaining in the Medina Lake to recharge the EA while the spring enhancement option recirculates the streamflow from the Guadalupe River near Gonzales back to the EA. The conflict, however, also arises within the environmental protection issue. By adopting the regional water plans maintaining/enhancing the springflow, flow at Calhoun Bay decreases.

Plans 1, 4, and 5 indicate a greater likelihood of implementation for regional Emergency Drought 
Management Rules since the average ending elevation measured at the $\mathrm{J} 17$ well falls below the critical implementation levels (650 and 640 feet). Moreover, the average springflow at Comal Springs is substantially reduced during drought conditions with cases realized where the springs cease to flow. This unexpected low springflow is caused by the use of the EA recharge and recovery Type 2 option. That option artificially recharges the EA during wet years, and allows additional use during drought conditions. Consequently, the EA use is 427,000 acft instead of 400,000 acft during drought conditions depleting springflow. Hydrologically, the results do not show that the EA effectively retains the artificial recharge into the dry years.

\section{Comparative Performance}

The desirability of the various plans depends on the weights a decision maker plans on the various outcomes combined undoubtedly with many other political or other concerns. It does appear that the model-developed plans dominate the regionally developed plans based on the quantitative analysis herein, although the political and implementation realities may dictate other choices. Table 4 ranks the plans based on the criteria herein and show from an economic viewpoint that the Optimal 400 Plan is preferable while from the springflow/environmental or water supply perspectives of the Optimal 200 Plan is preferred. The tradeoff between these items can be viewed as a benefit possibility frontier in which the region is willing to trade an economic benefit for another environmental benefit (Figure 4). If the total regional benefit starts at the 2050 base, by moving to the Optimal 200 Plan the region incurs marginal loss in the economic welfare but substantially gains in environmental benefits. On the other hand, by moving from the 2050 base to the Optimal 400, the region trades a small gain in the economic welfare with a substantial loss in the environmental benefit. The regional water management plans all perform in an inferior manner to the model-developed plans in terms of these criteria.

One might expect that a water management plan should increase regional welfare relative to a no development base but this is not the case for any of the regionally developed plans due to the costs of water option development. 


\section{Conclusions}

Fifty-seven water management options identified by SCTRWPG and five proposed long-term plans consisting of a mixture of these options are examined. The results show the region can gain welfare by developing water but because of high development costs that water supply for only $2 / 3$ of the projected growth needs to be developed for demand adjustments will dampen the demand as the costs of water development are factored into rates. The results also reveal a tradeoff between economic and environmental benefits. A slight decrease in economic benefit will result in a substantial increase in environmental benefits. The results also show that the model-developed plans dominate the regional water authority plans based on economic value and environmental impact. Furthermore, for whatever water management plan is adopted, the portion of the agricultural sector relying on the EA is most vulnerable and the EA non-agricultural sector gains are basically offset by the water development costs. 


\section{Footnotes}

1. The Texas Senate Bill 1477 intends to maintain minimum springflows at Comal and San Marcos Springs to protect threatened and endangered species.

2. Information presented in this section is based on reports or web-based materials supplied by the Edwards Aquifer Authority; the San Antonio Water System; the Texas Natural Resource Conservation Commission; HDR, Engineering. Inc (1991, 1993, and 1999); and Gregg Eckhardt.

3. Since return flows from agricultural use are very minor or non-existent (HDR 1991), only return flows from municipal and industrial uses are considered. The rate of return flow is $55 \%$ and $34 \%$ for municipal and industrial use, respectively. The return flow rate is an average of return flows by counties located in this region, and it is calculated as a percentage of water use obtained from the 1995 USGS: National Water-Use Data Files (http://water.usgs.gov/public/watuse/wudata/).

4. The 400,000 acft pumping limit is imposed by Texas Senate Bill 1477 as a way of maintaining minimum springflows at Comal and San Marcos Springs to protect endangered species. 


\section{References}

Brooke, A., Kendrick, D., and Meeraus A. GAMS: A user's guide release 2.25. Scientific Press, Redwood City, California, 1992.

Dantzig , G. B. “Linear Programming Under Uncertainty.” Management Science 1(1955):197-206.

Doorenbos, J., and W. O. Pruitt. "Guidelines for Predicting Crop Water Requirements." Food and Agriculture Organization of the United Nations. FAO Irrigation and Drainage Paper 33, Rome, 1977.

Eckhardt, G. A. “The Edwards Aquifer Home Page.” http://www.txdirect.net/users/eckhardt. 1998.

Griffin, R. C. and C. Chang. "Seasonality in Community Water Demand." Western Journal of Agricultural Economics 16(1991):207-217.

HDR Engineering, Inc. and Geraghty \& Miller, Inc. "Nueces River basin regional water supply planning study, Phase I, Vols. 1-3.” Report prepared for the Nueces River Authority, Uvalde, Texas, 1991.

HDR Engineering, Inc. and Espey, Huston and Association, Inc. "Guadalupe-San Antonio River basin recharge enhancement study, Vols. 1-3." Technical report prepared for the Edwards Aquifer Underground Water District, San Antonio, Texas, 1993.

HDR Engineering, Inc. "Water supply update for City of Corpus Christi Service area." Report prepared for the City of Corpus Christi, Texas, 1999.

Heimes, F. J. and R. R. Luckey. "Estimating 1980 Groundwater Pumpage for Irrigation on the High Plains in Parts of Colorado, Kansas, Nebraska, New Mexico, Oklahoma, South Dakota, Texas, and Wyoming.” USGS, Water Resources Investigation Report 83-4123, Denver, Colorado, 1983

Longley, G. "The Subterranean Aquatic Ecosystem of the Balcones Fault Zone Edwards Aquifer in Texas - Threats from Overpumping." Proceedings of the First International Conference on Ground Water Ecology, Ed. J. A. Stanford and J.J. Simons, Tampa, Florida, April 26-29, 291-300, 1992.

McCarl, B. A., K. O. Keplinger, C. Dillon, and R. L. Williams. "Limiting Pumping from the Edwards Aquifer: An Economic Investigation of Proposals, Water Markets and Springflow Guarantees." Water Resources Research, 35(1999):1257-68.

Renzetti, S. "An Economic Study of Industrial Water Demands in British Columbia, Canada." Water Resources Research, 24(1988):1569-1573.

South Central Texas Regional Water Planning Group web page http://www.watershedexperience.com/plans/. 2000.

Texas Water Development Board, Austin, Texas. "Surveys of Irrigation in Texas 1958, 1964, 1969, 1974, 1979, 1984, 1989, and 1994.” Report 347. 1996.

USGS, United States Geological Survey, Austin, Texas. "Recharge to and Discharge from the Edwards Aquifer in the San Antonio Area, Texas." various issues, the 1997 report is on http://tx.usgs.gov/reports/district/98/01/index.html. 
U.S. Water News Online. editor@uswaternews.com. November 1998.

Williams, J. R., C. A. Jones, J. R. Kiniry, and D. A. Spaniel. “The EPIC Crop Growth Model.” Transactions of the American Society of Agricultural Engineers 32(1989):497-511. 
Table 1. Water Management Options Used in the Alternative Plans ${ }^{\mathrm{a}}$

\begin{tabular}{|c|c|c|c|c|c|c|c|}
\hline Water Option & $\begin{array}{c}\text { Optimal } \\
400\end{array}$ & $\begin{array}{c}\text { Optimal } \\
200\end{array}$ & Plan $1^{b}$ & Plan2 & Plan3 & Plan4 & Plan5 \\
\hline \multicolumn{8}{|l|}{ Surface Water Diversion/Transfer } \\
\hline Lower Guadalupe River diversion & $x$ & $\mathrm{X}$ & $x$ & $\mathrm{X}$ & & & \\
\hline Colorado River in Colorado County & & & & & $\mathrm{x}$ & & \\
\hline Colorado River in Bastrop & & & & $\mathrm{x}$ & & & \\
\hline Joint development of water supply with CCC/LCC system & & & & & & $\mathrm{x}$ & \\
\hline Medina Lake & $\mathrm{X}$ & $\mathrm{X}$ & & & & & \\
\hline Canyon Reservoir & & & $\mathrm{X}$ & $\mathrm{X}$ & $\mathrm{X}$ & $\mathrm{X}$ & $\mathrm{X}$ \\
\hline Wimberley \& Woodcreek Reservoirs & & & $\mathrm{X}$ & $\mathrm{x}$ & $\mathrm{x}$ & $\mathrm{x}$ & $\mathrm{x}$ \\
\hline Cibolo Reservoir & & & $\mathrm{X}$ & & & & \\
\hline Lockhart Reservoir & & & $\mathrm{X}$ & & & & $\mathrm{X}$ \\
\hline Purchase/lease surface water irrigation rights & $\mathrm{x}$ & $\mathrm{x}$ & & & & & \\
\hline \multicolumn{8}{|l|}{ Groundwater Pumping/Recharge/Recovery } \\
\hline EA irrigation transfers & $X$ & $x$ & $\mathrm{x}$ & $\mathrm{x}$ & $\mathrm{x}$ & $\mathrm{x}$ & $\mathrm{X}$ \\
\hline EA recharge Type 2 & & & $X$ & $X$ & $X$ & $\mathrm{X}$ & $\mathrm{X}$ \\
\hline Guadalupe River diversion near Comfort & & & & & & & $X$ \\
\hline Springflow recirculation & & $\mathrm{x}$ & & $\mathrm{x}$ & $\mathrm{x}$ & & $\mathrm{x}$ \\
\hline Medina Lake irrigation reduction and recharge enhancement & $\mathrm{x}$ & $x$ & & $\mathrm{X}$ & $\mathrm{x}$ & & $\mathrm{x}$ \\
\hline Carrizo Aquifers pumping and/or recharge enhancement & $\mathrm{x}$ & $\mathrm{x}$ & $\mathrm{X}$ & $\mathrm{x}$ & $\mathrm{x}$ & $\mathrm{x}$ & $\mathrm{x}$ \\
\hline Gulf Coast Aquifers pumping and/or recharge enhancement & $\mathrm{X}$ & $\mathrm{x}$ & & & & $\mathrm{x}$ & \\
\hline Simsboro Aquifers pumping and/or recharge enhancement & & & $\mathrm{x}$ & $\mathrm{x}$ & & $\mathrm{x}$ & \\
\hline Trinity Aquifers pumping and/or recharge enhancement & & & $X$ & & & & $X$ \\
\hline
\end{tabular}

\footnotetext{
a Specific details of each water management options can be found at http: Ilwww.watershedexperience.com\planslplans.htm.

b Plan 1 is identified by local water supplies. Plan 2 focuses on the environmental impacts. Plan 3 emphasizes four criterion- unit cost of water, environmental impacts, reliability under drought, and public acceptance. Plan 4 is a cooperative effort in developing water supplies between the SCTR and the Lower Colorado and the Coastal Bend Regions. Plan 5 is based on the maximization of the EA recharge and recirculation system. The Optimal400 and Optimal200 are chosen among water options by the EDSIMR
} 
Table 2: Comparison of Economic and Hydrologic Effects of Water Management Alternative Plans

\begin{tabular}{|c|c|c|c|c|c|c|c|c|c|}
\hline & SON & $\begin{array}{c}2050 \\
\text { Base }^{\mathrm{a}} \\
\end{array}$ & $\begin{array}{c}\text { Optimal } \\
400\end{array}$ & $\begin{array}{c}\text { Optimal } \\
200 \\
\end{array}$ & Plan 1 & Plan 2 & Plan 3 & Plan 4 & Plan 5 \\
\hline \multicolumn{10}{|l|}{$\begin{array}{l}\text { Average Welfare Measures } \\
\text { (Million\$): }\end{array}$} \\
\hline Edwards Aquifer Agricultural Income & & 19.1 & $-33.3 \%$ & $-15.2 \%$ & $-48.7 \%$ & $-68.1 \%$ & $-68.9 \%$ & $-32.1 \%$ & $-69.1 \%$ \\
\hline Edwards Aquifer Non-agricultural Surplus & & 878.0 & $2.0 \%$ & $-0.3 \%$ & $-8.2 \%$ & $-7.2 \%$ & $-8.8 \%$ & $-12.1 \%$ & $2.3 \%$ \\
\hline Other Regional Agricultural Income ${ }^{c}$ & & 59.1 & $-1.1 \%$ & $0.02 \%$ & $0.01 \%$ & $-2.1 \%$ & $-2.1 \%$ & $0.02 \%$ & $-2.1 \%$ \\
\hline Other Regional Non-Agricultural Surplus & & 216.5 & $0.00 \%$ & $0.00 \%$ & $0.00 \%$ & $0.00 \%$ & $0.00 \%$ & $0.00 \%$ & $0.00 \%$ \\
\hline Total Regional Welfare & & 1232.8 & $0.8 \%$ & $-0.4 \%$ & $-6.6 \%$ & $-6.3 \%$ & $-7.4 \%$ & $-9.1 \%$ & $0.5 \%$ \\
\hline \multicolumn{10}{|l|}{ Agricultural Activity Measures $\left(10^{3}\right.$ acres $)$ : } \\
\hline Edwards Aquifer Irrigated Acres Harvested & & 74.5 & -39.1 & -24.8 & -51.6 & -63.5 & -63.5 & -37.0 & -63.5 \\
\hline Edwards Aquifer Dry Land & & 17.2 & -4.4 & -7.6 & 1.1 & 4.3 & -1.3 & -5.5 & -2.4 \\
\hline Purchased Edwards Aquifer Irrigated Land & & N/A & 41.7 & 30.9 & 48.3 & 59.1 & 59.1 & 39.1 & 59.2 \\
\hline Leased Edwards Aquifer Irrigated Land & & N/A & 1.9 & 1.5 & 2.2 & 0.0 & 5.7 & 3.4 & 6.6 \\
\hline Other Irrigated Land Harvested & & 153.1 & -0.02 & 0.01 & 0.01 & -14.1 & -14.1 & 0.01 & -14.1 \\
\hline Other Dry Land & & 68.2 & 0.0 & 0.03 & 0.0 & 12.7 & 12.7 & 0.0 & 12.7 \\
\hline Purchased Other Irrigated Land & & 0.0 & 0.0 & 0.0 & 0.0 & 12.7 & 12.7 & 0.0 & 12.7 \\
\hline \multicolumn{10}{|l|}{ Water Use Measures $\left(10^{3}\right.$ acre feet): } \\
\hline Edwards Aquifer Agriculture & $\begin{array}{l}\text { average } \\
\text { dry }\end{array}$ & $\begin{array}{l}116.3 \\
138.5\end{array}$ & $\begin{array}{l}-78.3 \\
-87.2\end{array}$ & $\begin{array}{l}-58.7 \\
-65.0\end{array}$ & $\begin{array}{l}-91.4 \\
-101.1\end{array}$ & $\begin{array}{l}-109.2 \\
-118.1\end{array}$ & $\begin{array}{l}-115.1 \\
-129.6\end{array}$ & $\begin{array}{l}-75.1 \\
-85.1\end{array}$ & $\begin{array}{l}-116.1 \\
-131.8\end{array}$ \\
\hline Edwards Aquifer Non-Agriculture & $\begin{array}{l}\text { average } \\
\text { dry }\end{array}$ & $\begin{array}{l}282.76 \\
261.36\end{array}$ & $\begin{array}{l}78.3 \\
87.2\end{array}$ & $\begin{array}{l}62.7 \\
55.7\end{array}$ & $\begin{array}{c}91.4 \\
101.1\end{array}$ & $\begin{array}{l}109.2 \\
118.2\end{array}$ & $\begin{array}{l}115.1 \\
129.6\end{array}$ & $\begin{array}{l}73.9 \\
85.1\end{array}$ & $\begin{array}{l}116.1 \\
131.8\end{array}$ \\
\hline
\end{tabular}


Table 2: Continued.

\begin{tabular}{|c|c|c|c|c|c|c|c|c|c|}
\hline & $\mathrm{SON}$ & $\begin{array}{c}2050 \\
\text { Base }^{\mathrm{a}}\end{array}$ & $\begin{array}{c}\text { Optimal } \\
400\end{array}$ & $\begin{array}{c}\text { Optimal } \\
200\end{array}$ & Plan 1 & Plan 2 & Plan 3 & Plan 4 & Plan 5 \\
\hline New Supply Agriculture & $\begin{array}{c}\text { average } \\
\text { dry }\end{array}$ & N/A & $\begin{array}{c}------ \\
0.06 \\
0.0\end{array}$ & $\begin{array}{c}1.4 \\
65.3\end{array}$ & $\begin{array}{c}\text { chan } \\
0.5 \\
2.0\end{array}$ & $\begin{array}{c}\text { rom the } \\
2.9 \\
0.0\end{array}$ & $\begin{array}{r}\text { Base } \\
8.7 \\
6.1\end{array}$ & $\begin{array}{l}0.0 \\
0.0\end{array}$ & $\begin{array}{l}9.8 \\
-- \\
8.2\end{array}$ \\
\hline New Supply Non- Agriculture & $\begin{array}{c}\text { average } \\
\text { dry }\end{array}$ & N/A & $\begin{array}{l}239.3 \\
273.4\end{array}$ & $\begin{array}{l}254.9 \\
303.1\end{array}$ & $\begin{array}{l}229.5 \\
260.0\end{array}$ & $\begin{array}{l}207.0 \\
243.0\end{array}$ & $\begin{array}{l}199.5 \\
231.3\end{array}$ & $\begin{array}{l}251.7 \\
275.4\end{array}$ & $\begin{array}{l}194.6 \\
225.3\end{array}$ \\
\hline Other Agriculture & $\begin{array}{c}\text { average } \\
\text { dry }\end{array}$ & $\begin{array}{l}250.2 \\
349.5\end{array}$ & $\begin{array}{l}-3.5 \\
-21.5\end{array}$ & $\begin{array}{l}0.1 \\
0.2\end{array}$ & $\begin{array}{l}1.8 \\
0.2\end{array}$ & $\begin{array}{l}-25.0 \\
-37.2\end{array}$ & $\begin{array}{l}-25.0 \\
-37.3\end{array}$ & $\begin{array}{l}0.1 \\
0.2\end{array}$ & $\begin{array}{l}-25.0 \\
-37.3\end{array}$ \\
\hline Other Non-Agriculture & $\begin{array}{c}\text { average } \\
\text { dry }\end{array}$ & $\begin{array}{l}405.9 \\
362.4\end{array}$ & $\begin{array}{c}0.0 \\
0.08\end{array}$ & 0.0 & $\begin{array}{l}-0.05 \\
-3.2\end{array}$ & 0.0 & 0.0 & 0.0 & 0.0 \\
\hline Total Regional Use & $\begin{array}{c}\text { average } \\
\text { dry }\end{array}$ & $\begin{array}{l}1056.3 \\
1112.0\end{array}$ & $\begin{array}{l}235.8 \\
251.9\end{array}$ & $\begin{array}{l}260.5 \\
359.4\end{array}$ & $\begin{array}{l}231.8 \\
259.1\end{array}$ & $\begin{array}{l}184.9 \\
205.7\end{array}$ & $\begin{array}{l}183.3 \\
200.0\end{array}$ & $\begin{array}{l}250.8 \\
275.7\end{array}$ & $\begin{array}{l}179.4 \\
196.2\end{array}$ \\
\hline Average Hydrologic Measures: & & & & & & & & & \\
\hline San Marcos Spring Flow (cfs/year) & & 102.7 & -6.7 & 11.6 & -9.0 & 2.9 & 2.5 & -5.6 & -3.6 \\
\hline Comal Spring Flow (cfs/year) & & 196.0 & -54.7 & 102.0 & -73.0 & 21.0 & 14.0 & -45.8 & -40.9 \\
\hline J17 Elevation (feet) & & 650.7 & -9.8 & 19.5 & -12.7 & 6.0 & 4.8 & -8.0 & -4.4 \\
\hline Sabinal Elevation (feet) & & 760.5 & -5.8 & 33.0 & -7.2 & 27.6 & 27.0 & -4.1 & 15.4 \\
\hline Min Comal Spring Flow (cfs/month) & & 68.8 & -48.0 & 131.2 & -68.8 & 12.5 & 4.2 & -55.6 & -63.6 \\
\hline Corpus Bay Inflow $\left(10^{3}\right.$ acft $)$ & & 1025.7 & 19.1 & 4.6 & 12.0 & -1.14 & 2.1 & -1.1 & -2.3 \\
\hline Calhoun Bay Inflow (10 $\mathrm{acft})$ & & 3347.8 & -66.4 & -260.7 & -29.6 & -268.0 & -109.3 & -114.3 & -249.5 \\
\hline
\end{tabular}

a 2050 Base refers to a scenario under the 2050 projected water demand with a restriction of 400,000 acft pumping limit of the EA but without a water management alternative plan. The other non-base plan scenarios are with a restriction of 400,000 acft pumping limit of the EA and with a water management alternative plan.

b Average refers to the expected results weighted by probability of recharge state of nature.

c Other refers to activities or measures related to the agricultural or non-agricultural sectors using water supplied from surface water or CarrizoWilcox groundwater. 
Table 3: Cost Analyses of Water Management Alternative Plans

\begin{tabular}{|c|c|c|c|c|}
\hline Water Alternative Plan & & Total Cost $\left(\$ 10^{6}\right)$ & $\begin{array}{l}\text { Total New Supply } \\
\qquad\left(10^{3} \mathrm{acft}\right)\end{array}$ & Unit Cost (\$/acft) \\
\hline Optimal400 & $\begin{array}{l}\text { average } \\
\text { drought }\end{array}$ & $\begin{array}{l}112.9 \\
125.5\end{array}$ & $\begin{array}{l}239.4 \\
273.4\end{array}$ & $\begin{array}{l}471.5 \\
459.1\end{array}$ \\
\hline Optimal200 & $\begin{array}{l}\text { average } \\
\text { drought }\end{array}$ & $\begin{array}{l}132.9 \\
183.5\end{array}$ & $\begin{array}{l}256.4 \\
368.4\end{array}$ & $\begin{array}{l}518.5 \\
498.3\end{array}$ \\
\hline Plan 1 & $\begin{array}{l}\text { average } \\
\text { drought }\end{array}$ & $\begin{array}{l}201.6 \\
219.6\end{array}$ & $\begin{array}{l}230.0 \\
262.0\end{array}$ & $\begin{array}{l}876.4 \\
838.4\end{array}$ \\
\hline Plan 2 & $\begin{array}{l}\text { average } \\
\text { drought }\end{array}$ & $\begin{array}{l}192.4 \\
207.3\end{array}$ & $\begin{array}{l}209.9 \\
243.0\end{array}$ & $\begin{array}{l}916.6 \\
853.1\end{array}$ \\
\hline Plan 3 & $\begin{array}{l}\text { average } \\
\text { drought }\end{array}$ & $\begin{array}{l}205.4 \\
227.4\end{array}$ & $\begin{array}{l}208.3 \\
237.4\end{array}$ & $\begin{array}{l}986.1 \\
958.0\end{array}$ \\
\hline Plan 4 & $\begin{array}{l}\text { average } \\
\text { drought }\end{array}$ & $\begin{array}{l}269.2 \\
268.0\end{array}$ & $\begin{array}{l}222.0 \\
246.6\end{array}$ & $\begin{array}{l}1,212.6 \\
1,087.0\end{array}$ \\
\hline Plan 5 & $\begin{array}{l}\text { average } \\
\text { drought }\end{array}$ & $\begin{array}{l}106.9 \\
111.1\end{array}$ & $\begin{array}{l}204.4 \\
233.5\end{array}$ & $\begin{array}{l}523.0 \\
475.8\end{array}$ \\
\hline
\end{tabular}


Table 4: Ranked Assessment of Water Management Plans

\begin{tabular}{|c|c|c|c|c|c|c|c|}
\hline Assessment Criteria & $\begin{array}{c}\text { Optimal } \\
400\end{array}$ & $\begin{array}{l}\text { Optimal } \\
200\end{array}$ & Plan 1 & Plan 2 & Plan 3 & Plan 4 & Plan 5 \\
\hline Welfare Effect ${ }^{\mathrm{a}}$ & 1 & 2 & 5 & 4 & 6 & 7 & 3 \\
\hline Environment Effect ${ }^{\mathrm{a}}$ & 6 & 1 & 7 & 2 & 3 & 4 & 5 \\
\hline $\begin{array}{l}\text { Tradeoff between Welfare } \\
\text { and Environment Effects }\end{array}$ & 2 & 1 & 6 & 4 & 5 & 7 & 3 \\
\hline $\begin{array}{l}\text { Emergency Drought } \\
\text { Management Rules } \\
\text { Implementation }^{\mathrm{b}}\end{array}$ & Stage I & None & Stage II & None & None & Stage I & Stage I \\
\hline $\begin{array}{l}\text { a Ranked from } 1 \text { to } 7 \text { where } \\
\text { The purpose of the emerg } \\
\text { drought management rule } \\
\text { the J-17 well level is betw } \\
640 \text { feet. Stage III applie }\end{array}$ & $\begin{array}{l}\text { presents t } \\
\text { drought } \\
\text { idered in } \\
540-650\end{array}$ & $\begin{array}{l}\text { est plan. } \\
\text { agement } \\
\text { study is } \\
\text { Stage } \\
\text { ell level }\end{array}$ & $\begin{array}{l}\text { les is to } 1 \\
\text { sed on th } \\
\text { ppplies } w\end{array}$ & $\begin{array}{l}\text { ct the } \\
17 \text { wel } \\
\text { the J-1 }\end{array}$ & $\begin{array}{l}\text { igflow. } \\
\text { el. Sta } \\
\text { ell leve }\end{array}$ & $\begin{array}{l}\text { he emer } \\
\text { I applie } \\
\text { betwee }\end{array}$ & $\begin{array}{l}\text { yency } \\
\text { when } \\
630-\end{array}$ \\
\hline
\end{tabular}


**** Map is save as *829fig1.ppt (powerpoint)

Figure 1. Map of the South Central Texas region study area including the Edwards Aquifer region and Nueces, San Antonio, and Guadalupe River basins. 


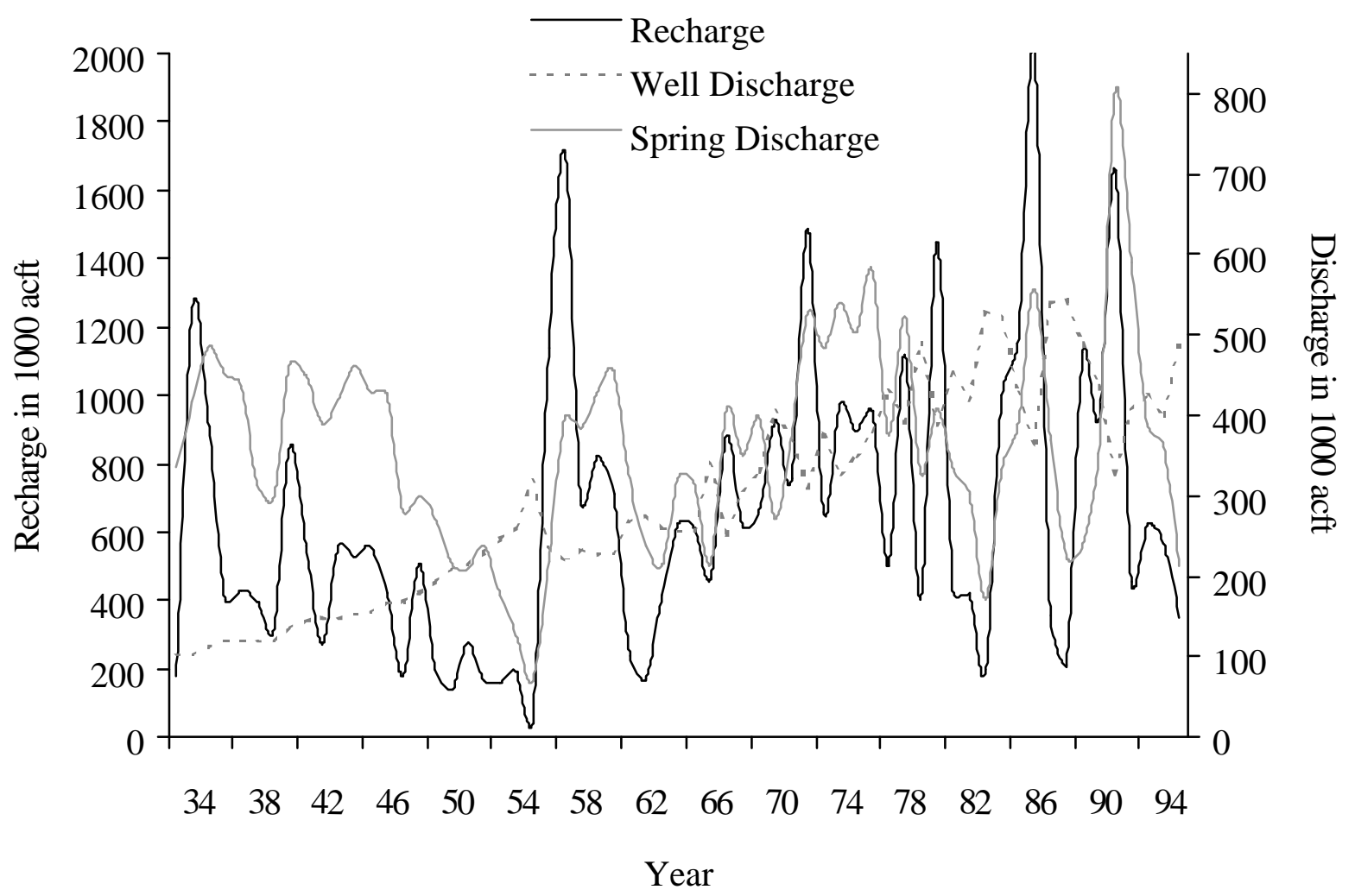

Figure 2. Historical Edwards Aquifer Recharge and Discharge from 1934 to 1996 


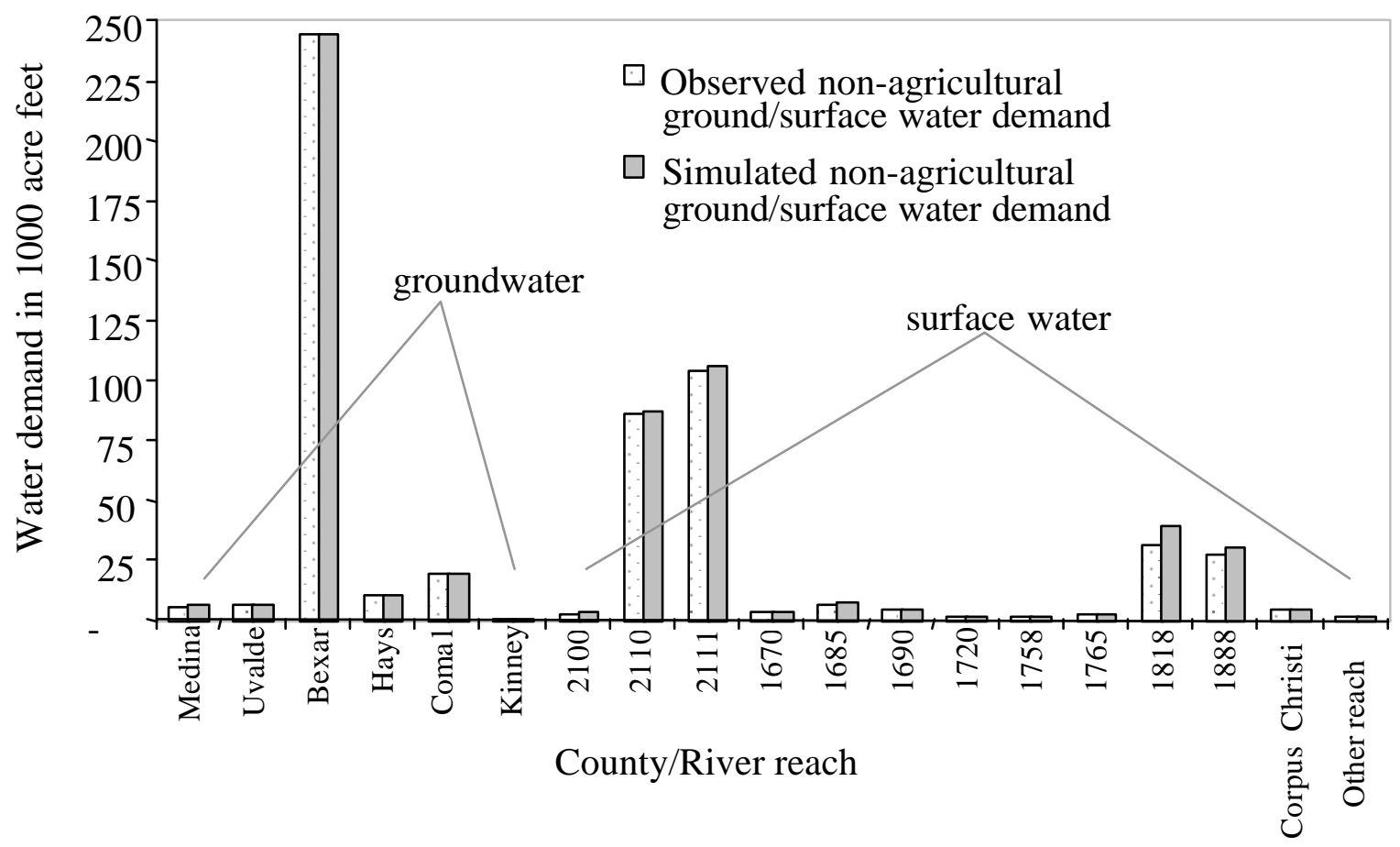

(a) Ground/surface water demand

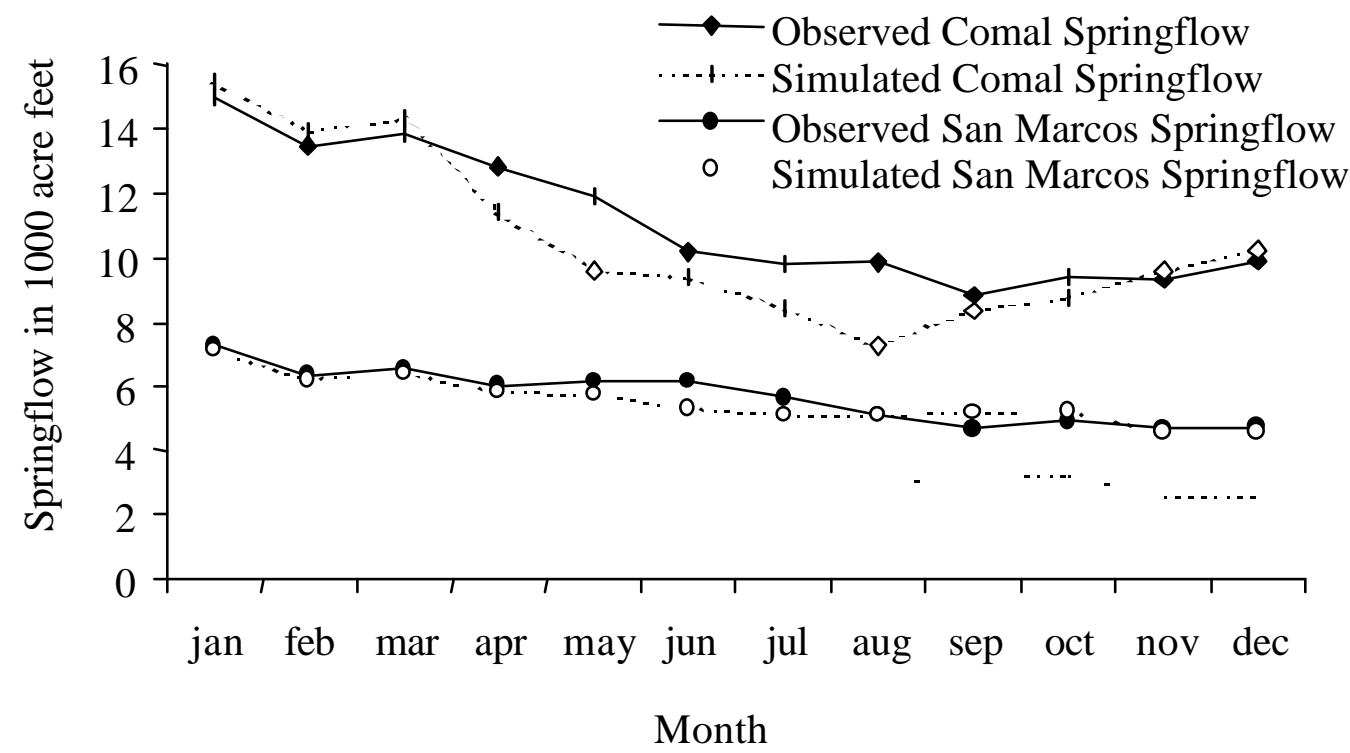

(b) Springflow at Comal and San Marcos Springs

Figure 3. Comparison of Observed and Simulated Springflow at Comal Springs 


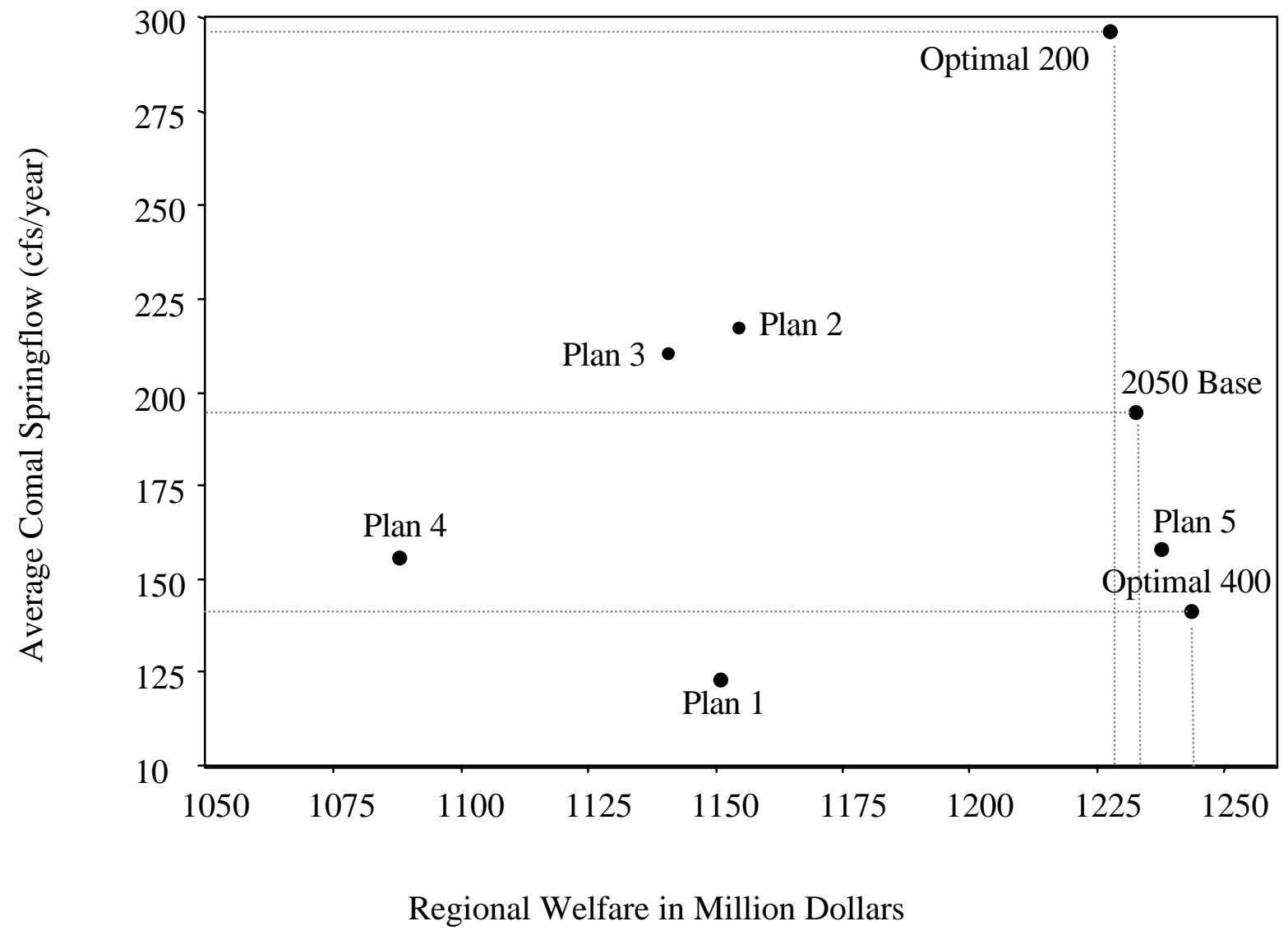

Figure 4: Comparison of economic and environmental effects of the South Central Texas water management plan. 


\section{Appendix A}

The water management alternative options considered in the analysis, together with the codes used in the SCTRWP when appropriate, are as follows:

\section{Local/Conservation/Reuse/Exchange}

L-14

Transfer of unappropriated and/or reclaimed water to Corpus Christi via Choke Canyon Reservoir.

Description: San Antonio Water System (SAWS) reclaimed water and unappropriated water in the San Antonio River from a point near Falls City area is transferred to Choke Canyon Reservoir to enhance the firm yield of the Choke Canyon Reservoir and Lake Corpus Christi (CCR/LCC) System.

L-15 Purchase or lease EA irrigation water for municipal and industrial use.

Description: Irrigation permit holders are allowed to sell or lease up to $50 \%$ of irrigation permits.

L-20 Transfer SAWS reclaimed water to Coleto Creek Reservoir.

Description: A portion of SAWS return flows would be diverted from the San Antonio River near Goliad to Coleto Creek Reservoir, in exchange for transferring Guadalupe River water rights to the Saltwater Barrier and enhancing the firm yield of Canyon Reservoir.

\section{Aquifer Pumpage/Recharge/Recovery}

CZ-10C, D Carrizo Aquifer.

Description The development of a 40,000, 75,000, or 220,000 acft of water from the Carrizo-Wilcox Aquifer is diverted to supply municipal and industrial demands in the major municipal demand center of the SCTR.

SCTN-2a Carrizo-Wilcox Aquifer.

SCTN-2b Gulf Coast Aquifer.

Description Local groundwater supply from Carrizo and Gulf Coast Aquifers are pumped to supply irrigation used EA water.

SCTN-3c Simsboro Aquifer.

Description The developed Simsboro groundwater is delivered from the well field to the Colorado River west of Bastrop, Plum Creek, and the major municipal and industrial demand center of the SCTR.

SCTN-8 Trinity Aquifer.

Description Local groundwater supply from Trinity Aquifer is pumped to supply irrigation used EA water.

L-18 EA recharge from natural drainage - Type 2 (c).

Description: This option artificially recharges the EA and recovery is later when needed. The amount of artificial recharge is based on the historical recharge. Type 2 recharge structures are located within or directly over the EA recharge zone.

SCTN-7 Carrizo-Wilcox Aquifer recharge enhancement. 
Description: This option artificially recharges the Carrizo-Wilcox Aquifer with streamflow from the Nueces River in Zavala County. This enhanced recharge would be available for pumping by local irrigators or for pumpage and transfer to a municipality during drought years.

SCTN-6 Edwards Aquifer optimization - springflow recirculation.

Description The streamflow from the Guadalupe River near Gonzales is recirculated back to the EA as a means to increase the total EA storage.

SCTN-1a Aquifer storage and recovery.

Description The Carrizo Aquifer is artificially recharged from streamflow during wet years and is recovered to support water suppliers in the major municipal and industrial demand center during drought years.

\section{River or Lake Diversion with Storage}

C-13C Colorado River at Bastrop.

Description: A water supply of 50,000 acft is annually purchased from the Lower Colorado River Authority (LCRA) and diverted from the Colorado River near Bastrop to water treatment plants at the major municipal demand center of the South Central Texas Region (SCTR).

C-17a The Colorado River in Colorado County.

Description: A water supply of 125,000 acft is annually purchased from LCRA and diverted from the Colorado River in Colorado County to water treatment plants at the major municipal demand center of the SCTR.

C-17b The Colorado River in Wharton County.

Description: A water supply of 70,000 acft is annually purchased from private and other interests and diverted from the Colorado River in Wharton County to water treatment plants at the major municipal demand center of the SCTR.

G-30 Guadalupe River diversion near Comfort to recharge.

Description: Streamflow in the Guadalupe River between Comfort and Center Point is diverted to the Medina River then to the Medina Lake System where this streamflow would then be recharged to the EA through the Medina Lake recharge. This enhanced recharge is later recaptured through a recharge recovery permit.

G-38c Guadalupe River diversions at Gonzales.

Description: Unappropriated streamflow from the Guadalupe River at Gonzales is diverted to regional water treatment plants.

\section{Existing Reservoirs}

G-32 Diversion of Canyon Reservoir flood storage.

Description: Water from Canyon flood storage is artificially used to recharge the EA. This enhanced recharge is then recovered during drought years.

G-15C Canyon Reservoir released to Lake Nolte.

Description Uncommitted stored water from Canyon Lake is purchased and delivered to regional water treatment plants. 
S-13B Medina Lake

Description Existing irrigation water rights are purchased through the 16,000 acres of land retirement which increases 45,856 acft of water in Medina Lake which in turn enhances the EA recharge by 9,873 acft via Medina Lake recharge.

\section{Potential New Reservoirs}

G-21 Lockhart Reservoir.

Description Streamflow near Luling is diverted to Lockhart Reservoir to provide additional water to the local area.

G-24 Wimberley \& Woodcreek Reservoir.

Description A water treatment plant would be constructed near the South end of Canyon Reservoir to provide additional water to the local area.

S-15C Cibolo Reservoir.

Description Water from the proposed reservoir is diverted to water treatment plants at the major municipal demand center of the SCTR.

S-15Da Cibolo Reservoir with imported water from the San Antonio River.

$\mathrm{S}-15 \mathrm{Db} \quad$ Cibolo Reservoir with imported water from the San Antonio and Guadalupe Rivers.

S-15Dc Cibolo Reservoir with imported water from the San Antonio, Guadalupe, and Colorado Rivers.

Description Streamflow from the San Antonio River near Floresville, Guadalupe River near Cuero, and Colorado River near Columbus is diverted to supplement Cibolo Reservoir firm yield and transmitted to water treatment plants at the major municipal demand center of the SCTR.

S-15Ea Cibolo Reservoir with imported water from the Guadalupe River at the Saltwater Barrier.

$\mathrm{S}-15 \mathrm{~Eb} \quad$ Cibolo Reservoir with imported water from the Guadalupe River at the Saltwater Barrier and the Colorado River below Garwood.

Description The firm yield of the Cibolo Reservoir is supplemented with unappropriated water from the Guadalupe River at the Saltwater Barrier and from the Colorado River, then delivered to water treatment plants.

S-16C Goliad Reservoir.

Description A firm yield of the proposed Goliad Reservoir is diverted to water treatment plants at the major municipal demand center of the SCTR.

\section{Cooperative Options}

SCTN-11 Purchase/lease surface irrigation water rights.

Description This option purchases or leases unused irrigation surface water rights from (rice) farmers in the Lower Guadalupe, Colorado, and Lavaca River Basins for municipal and industrial use.

SCTN-14a, b Joint Development of Water Supply with Corpus Christi. 
Description This option enhances water supply in the CCR/LCC System by purchasing water from the Guadalupe River at the Saltwater Barrier under existing water rights and groundwater from the Gulf Coast Aquifer (SCTN-14a) and purchasing unappropriated streamflow and/or reclaimed water from the San Antonio River near Falls City (SCTN-14b). This enhanced supply is diverted to water treatment plants in the SCTR.

SCTN-16a,b,c Lower Guadalupe River diversion.

Description This group of water supply options involves the diversion of unappropriated streamflow and existing water rights at the Guadalupe River Saltwater Barrier, presently uncommitted supply from Canyon Reservoir, and groundwater from the Gulf Coast Aquifer to water treatment plants at the major municipal demand center of the SCTR.

NEW-001 Use the SAWS recycled water.

Description This option is suggested by the SAWS water resources plan (page 46). The SAWS recycles EA ground water return flow from the wastewater treatment plants. Of 130,000 acft per year of water treated at the plants, 35,000 acft is available for the development of the recycled water which is mainly used for irrigation of public parks and golf courses, and industrial processing and cooling uses; 40,000 acft is reserved for City public service; and 55,000 acft is returned to the San Antonio River.

NEW-002 Diversion of Medina Lake.

Description This option is suggested by the SAWS Water Resources Plan (page 51). The annual firm yield and a unit cost per acre foot is obtained from this Water Resource Plan in Table 3 on page 53. 


\section{Appendix B}

The following section presents the specific objective function and constraints.

\section{Objective Function}

The objective function maximizes the expected net benefits (benefits minus costs) of water use by municipal, industrial, and agricultural sectors. Water use within each sector is drawn from either groundwater or surface water (w). Benefits from using groundwater and surface water in municipal and industrial sectors are determined by the areas under the constant elasticity municipal and industrial demand curves whereas benefits from using groundwater and surface in the agricultural sector are represented by the net agricultural income derived from irrigated and dryland crop production (CROPPROD). Total water costs consist of pumping/diverting costs for the agricultural and nonagricultural sectors and water management plan costs. Fixed costs associated with each water management alternative option $(p)$ incur only if that water management alternative option is adapted (BUILDPLAN) whereas variable costs depend on the amount of water used (NEWWATER). This objective function is maximized subjected to a set of constraints including ground/surface water demand and supply (both existent and newly developed supplies) balance, agricultural production activities (c), hydrologic regressions, nonnegative conditions for decision variables, and binary conditions for water development decisions. The objective function is probabilistically weighted by the state of nature or weather conditions $(r)$, to reflect the stochastic nature of weather (all variables are typed in upper case and all parameters are typed in lower case.).

$$
\begin{aligned}
& \sum_{r} \operatorname{prob}_{r} \cdot\left(\sum_{c} \sum_{w}\left(\text { irrincome }_{r c w} \text { CROPPROD }_{r c w}\right)\right. \\
&+\sum_{w} \int M U N_{r w} \mathrm{dMUN}+\sum_{w} \int I N D_{r w} \mathrm{dIND} \\
&-\sum_{c} \sum_{w} \operatorname{agcos} t^{*} A G W A T E R_{r c w}-\sum_{w} m i \cos t^{*}\left(\operatorname{MUN}_{r w}+\text { IND }_{r w}\right) \\
&\left.-\sum_{p} \text { fixedcost }_{p} *\left(\text { BUILDPLAN }_{p r}\right)-\text { variablecost }_{p} *\left(N E W W A T E R_{p r}\right)\right)
\end{aligned}
$$

\section{Initial Edwards Aquifer Elevation}

The initial Edwards Aquifer elevation (INITIALLEVEL i $_{\mathrm{i}}$ ) measured at J17 and Sabinal well 
indices is the average of ending the Edwards Aquifer elevation $\left(E N D L E V E L_{\mathrm{i}}\right)$ weighted by the probability associated with each state of nature in order to allow the Edwards Aquifer level to fluctuate with the weather.

$$
\text { INITIALLEVEL }_{i}=\sum_{r}\left(\text { prob }_{r} * E^{2 N D L E V E L} L_{i r}\right) \quad \forall i .
$$

\section{Ending Edwards Aquifer Elevation}

The ending Edwards Aquifer elevation is a function of the initial elevation, the Edwards Aquifer groundwater use (EDUSE), and the Edwards Aquiver recharge (recharge). The $\alpha_{i}$ represents the regression parameter that was previously estimated in the Edwards Aquifer model using the GWSIM-IV Edwards Aquifer Simulation Model

$$
\text { ENDLEVEL }_{i r}=\alpha_{0}+\alpha_{1} \text { recharge } e_{r}+\alpha_{2} \sum_{m} E D U S E_{m r}+\alpha_{3} \text { INITIALLEVEL }_{i} \quad \forall i \text { and } r .
$$

Springflow Regression

Springflows are generated by a regression which is a function of the initial Edwards Aquifer elevation levels at J17 and Sabinal index wells, the Edwards Aquifer monthly recharge, and the aggregated Edwards Aquifer water use. $\omega$ and $\alpha$ represent the regression parameters that were previously estimated in the EDSIMR

$$
S P R I N G_{m r}=\grave{\mathrm{u}}_{0}+\grave{\mathrm{u}}_{i} \text { INITIALLEVEL }_{i}+\alpha_{1} \text { rech } \arg e_{m r}+\alpha_{2} \text { EDUSE }_{m r} \quad \forall \mathrm{m} \text { and } \mathrm{r} \text {. }
$$

\section{Crop Mixes}

A crop mix constraint implies that a farmers' crop production decision is a convex combination of crop mix (CROPMIX) in which all of the lands used (irrigated or dry land) for a crop grown within a county follows the historical crop mixes (mixdata) observed on irrigated and dry land acres by crop and county from the years 1975 to 1996 as well as crop mixes obtained from the 1994 farm program survey indicating what would happen if the farm program was eliminated.

$$
\text { CROPPROD }_{y c w}=\sum_{y}\left(\text { mixdata }_{y c w} * \text { CROPMIX }_{y c w}\right) \quad \forall c \text { and } w .
$$




\section{Irrigated Land}

The constraint limits irrigated crop production to irrigated land acres (LAND) available but allows irrigated land acres to be converted to dryland (TODRY)

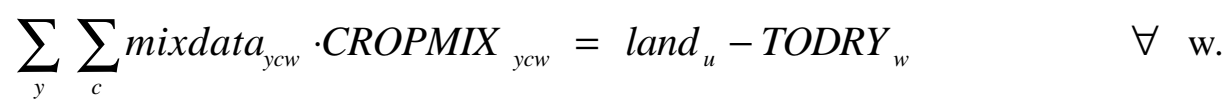

Dryland

This constraint limits dryland acres to those available plus those converted from irrigated acres (sprinkler or furrow)

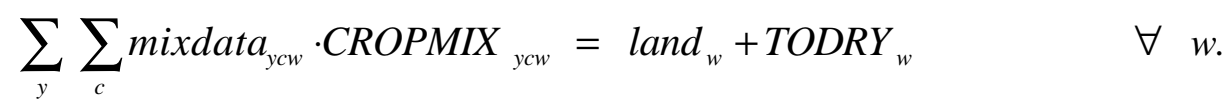

\section{Irrigation Water Demand}

The irrigated crop water demand by type of water is also limited to be less than or equal to water available for irrigation by type of water

$$
\left.\sum_{c} \text { (watrequire }_{c m r} \cdot \text { CROPPROD }_{r c w}\right) \leq \text { AGWATER }_{m r w} \quad \forall m \text { and } r .
$$

\section{Edwards Aquifer Pumping Balance}

The total water demand for agriculture, municipality, and industry using the groundwater pumped from the Edwards Aquifer is limited to be equal to the total amount of the groundwater pumped from the Edwards Aquifer. In general, the amount of water pumped from the Edwards Aquifer is unlimited but is limited to 400,000 acft per year when the pumping limit is imposed

$$
\begin{aligned}
& \text { EDUSE }_{m r}=\text { seasonal }_{m^{\prime \prime m u n}} * \text { MUN }_{r^{\prime \prime} e d^{\prime \prime}}+\text { seasonal }_{m^{\prime \prime} i n d^{\prime \prime}} * \operatorname{IND}_{r^{\prime \prime} e d^{\prime \prime}}+\text { AGWATER }_{m r^{\prime \prime} e d "} \quad \forall m \text { and } r . \\
& M U N_{r^{\prime e d "}}+I N D_{r^{\prime \prime} e d^{\prime \prime}}+\sum_{m} A G W A T E R_{m r^{\prime \prime e d "}} \leq \text { pump }_{r} \quad \forall m \text { and } r .
\end{aligned}
$$

\section{Irrigated Water}

A water demand and supply balance limits water demand is less than or equal to the total amount supply available for each water type

$$
\text { AGWATER }_{m r w} \leq \text { watsupply }_{m r w} \quad \forall m, r \text {, and w. }
$$


River System

The river system portrays a hydrological relationship among upstream, downstream, as well as instream flows, reservoirs/lakes release and spill, diversions, system channel loss, return flow, aquifer recharge, springflow, and water transfers

$$
\begin{aligned}
& \text { FLOW }_{\text {smr }}+\text { seasonal }_{m^{\prime \prime m u n "}} \text { MUN }_{r w^{\prime \prime s u r "}}+\text { seasonal }_{m^{\prime \prime i n d}} I N D_{r w^{\prime \prime} s u r^{\prime \prime}}+\sum_{\text {upriver }} \text { LOSS }_{\text {smr }} \\
& -\sum_{u p} \text { Flow }_{u p, m r}-\text { INFLOW }_{s m r}-\text { RETURNFLOW }_{s m r}-\text { SPRING }_{s m r}+\text { RECHARGE }_{s m r} \\
& -\sum_{p} N E W W A T E R_{\mathrm{smrp}} \leq 0 \\
& \forall m, r \text {, and } \mathrm{w}
\end{aligned}
$$

\section{Water Management Alternative Plan}

The decision whether a water management alternative plan, $p$, should be adapted is viewed as a binary choice, to adapt or not to adapt. If adapted, a water management alternative plan's fixed cost is considered in the objective function. The amount of water that can be drawn from each water management alternative plan is limited by the capacity of each water management alternative plan and its corresponding variable cost is considered in the objective function

$$
\begin{aligned}
& \text { BUILDPLAN }_{p} \in\{0,1\} \\
& \sum_{s} \text { NEWWATER }_{\text {smrp }} \leq \text { capacity }_{p} * \text { BUILDPLAN }_{p} \quad \forall m, r, \text { and } \mathrm{w}
\end{aligned}
$$

\section{Other Features and Constraints}

There are a number of other features and constraints used in the study but not presented in the Appendix. For example, the pumping lift constraint is set as a function of J17 and Sabinal wells ending elevation level. A full description of the model can be found in McCarl et al. 


\section{Appendix C}

Key Model Assumptions

There are a few specific assumptions used in the EDSIMR that should be addressed. First, the annual pumping limit of the Edwards Aquifer is set at 400,000 acft as mandated by Texas Senate Bill 1477. Second, we assumed a current being installed recycled water system operates at full capacity (130,000 acft per year) and provides 35,000 acft available for municipal users, 40,000 acft reserved for the City Public Service, and 55,000 acft returned to the San Antonio River. Third, the Lake Corpus Christi-Choke Canyon Reservoir System (CCR/LCC) operates under the 1995 TNRCC Agreed Order regarding freshwater inflows to the Corpus Christi estuary. Fourth, the interbasin transfer of 41,840 acft per year from Lake Texana in Jackson County to Corpus Christi has taken place. Fifth, new developed water under each water management plan is delivered to a water treatment plant owned and operated by SAWS, except for water from Lockhart and Wimberley Reservoirs which is delivered to Hays County. Last, irrigated crop water demands are treated as a heterogeneity in which irrigated crop water demands are categorized according to sources of available water supplies. As a result, the substitutability of water supply is not allowed. For instance, irrigated crop growing on lands having only access to the groundwater pumped from the Edwards Aquifer will not be allowed to use the water from other sources such as the Carrizo Aquifer or surface streams when there is inadequate supply, unless water management option facilities are built. 